\title{
Mass Casualty of Scombroid Fish Poisoning among Factory Workers in Obour City
}

\author{
Heba .Youssef .S, Mona K. Mousa ${ }^{1}$ and Saad.Nagib ${ }^{2}$ \\ ${ }^{1}$ Forensic Medicine \& Clinical Toxicology Department Faculty of Medicine Ain Shams University \\ ${ }^{2}$ Poison Control Center Ain Shams University Hospitals, Cairo, Egypt.
}

\begin{abstract}
On the first of January 2013 one hundred and seventy five workers in one of El Obour factories were complaining of nausea, vomiting, abdominal cramps and diarrhea after eating a mackerel fish lunch meal served to them at their work at 1 P.M. They were rushed first to emergency department "ED" of El Salam general hospital where they were diagnosed as food poisoning and advised to be transported to the poison control center "PCC" of Ain Shams University "ASU." The faculty dean and PCC director alerted the preventive control unit in ministry of health about suspected scombroid food poisoning. An emergency management plan for mass casualty was established. The patients were triaged under supervision of two clinical toxicologist teams and grouped according to triage colored tags into yellow tag cases (Group I) ;they included 65 cases with mild clinical manifestations. Green tag cases (Group II); they included 100 cases with moderate manifestations and red tag cases (Group III); they included 10 cases presented with severe clinical manifestations. Demographic data showed that $60 \%$ were males and $40 \%$ were females.There was non-significant statistical difference regarding delay time between the three studied groups. The clinical assessment results revealed highly significant statistical difference between the studied groups regarding gastrointestinal manifestations (in the form of diarrhea, abdominal colic, and tingling and burning peppery taste sensation), and cardiopulmonary manifestations (in the form of hypotension, tachycardia, bronchospasm, positive Trendelenberg's position). Neurological manifestations in the form of headache were highly significant in the studied groups and significant syncope only in group III. The skin manifestations among the studied groups showed highly statistical significant facial flushing, sweating and itching. Microbiological examination of biological samples (stool and gastric aspirate) and fish samples (fried and raw mackerel fish) revealed positive Bacillus cereus and Staphylococcus aureus. Chemical examination of fish samples revealed highly significant increase in histamine levels in fried and raw mackerel fish samples when compared with their permissible levels according to food and drug administration values. There was highly significant statistically difference between the studied groups of patients with acute scombroid fish poisoning as regards the percentage of different lines of treatment received at emergency room and inpatient wards of both PCC and ED ASU hospitals. The outcome showed complete cure with fully discharged cases with no morbidities or mortalities. In conclusion mass casualty of scombroid fish poisoning incident could pass safely if the emergency management plan was successfully established. The study recommends the necessity of increasing the number of available beds in PCC to enlarge its capabilities of facing mass casualty incidents. Also the study recommends the necessity of strict preservation of fish especially those belonging to scombroidea family (mackerel and tuna) in cool temperature to avoid bacterial contamination and the increase in histamine level.
\end{abstract}

Keywords Scombroid food poisoning, histamine, mass casualty

\section{Introduction}

combroid food poisoning is an endogenous food borne illness that results from eating unfrozen fish. However it is often missed because it resembles an allergic reaction.

It is most commonly reported with mackerel, tuna, bluefish, mahi-mahi, bonito, sardines, anchovies, and related species of fish that were inadequately refrigerated or preserved after being caught. The syndrome derived its name because early descriptions of the illness noted an association with scombroidea fish (e.g., large dark meat marine tuna, albacore, and mackerel); however, the Centers for Disease Control and Prevention, 2011 have identified other, non scombroid vectors, such as mahi-mahi and 
amberjack. One of the toxic agents implicated in scombroid poisoning is histadine which is broken down into histamine (Hungerford, 2010).

Unlike many types of food poisoning, this form is not brought about by ingestion of a bacterium or virus. Histadine exists naturally in many types of fish, and at temperatures above $16^{\circ} \mathrm{C}\left(60^{\circ} \mathrm{F}\right)$ on air contact it is converted to the biogenic amine histamine via the enzyme histidine decarboxylase produced by enteric bacteria including Morganella morganii (this is one reason why fish should be stored at low temperatures). Histamine is not destroyed by normal cooking temperatures, so even properly cooked fish can be affected. Histamine is a mediator of allergic reactions, so the symptoms produced are those one would expect to see in severe allergic responses. Symptoms of poisoning can be shown within just minutes, and up to two hours, following consumption of unfrozen fish and usually last for approximately ten to fourteen hours and rarely exceed one to two days (Goldfrank, 2013). Symptoms consist of skin flushing, throbbing headache, oral burning, abdominal cramps, nausea , diarrhea palpitations, a sense of unease, and rarely collapse or loss of vision. Physical signs may include a diffuse blanching erythema , tachycardia, wheezing, and hypotension or hypertension. People with asthma are more vulnerable to respiratory problems such as wheezing or bronchospasm.

Treatment is in the form of supportive care such as fluids and oxygen. Oral anti-histamines are very effective, showing an improvement within 10-15 minutes (Lehane and Olley, 2013).

\section{Aim of the work}

The study aims at first to analyze cases exposed to scombroid food poisoning received at the PCC and ED ASU hospitals on the first of January 2013, from the demographic, clinical, laboratory, therapeutic and outcome points of view. Second to evaluate the efficacy of the emergency management plan for mass casualty that was established to manage such cases.

\section{Methods}

In this study the total number of scombroid cases were 175 which were beyond the capabilities of PCC (120 beds at time of the study) so the faculty dean, the vice dean, PCC director, general hospital director, head of forensic medicine and clinical toxicology department and medical crisis and disaster management unit director apply the emergency management plan for mass casualty incidents (MCI).

The rational of this plan is the clinical management of large number of cases who were requiring additional staff, resources, communication, and preparation. The policy of this plan includes all areas of management in poison control center PCC and emergency department ED of Ain Shams University hospital.

The following procedures were applied:

Alert and notification of authority mainly ministry of health, chief executive office CEO of
ASU hospital, poison control center medical staff and medical director of emergency department ED. The ministry of health central lab was responsible for collecting and examining all biological samples from poisoned cases and fish (raw and fried) for microbiological and chemical methods.

Triaging and grouping of patients : All patients(total 175 ) were arrived via emergency medical services EMS and rapidly triaged by the ambulance triage officer into 115 cases were directed to the PCC and 65 cases were directed to ED -building entrance to be further triaged under supervision of two clinical toxicologist teams and grouped according to triage colored tags into:

Yellow tag cases (Group I): they included 65 cases with mild clinical manifestations. They were presented with headache, nausea, vomiting, dizziness and abdominal cramps. These were relatively stable patients who were demanding prompt medical attention. Green tag cases (Group II): they included 100 cases with moderate manifestations who presented with flushing, skin rash, vomiting and diarrhea. These cases can wait for appropriate treatment. Red tag cases (Group III): they included $\mathbf{1 0}$ cases presented with severe abdominal manifestations, neurological, hypotension, tachycardia, bronchospasm, positive Trendelenberg's position and severe itching. These cases were in need of immediate life-saving care. Red and yellow tags cases were admitted to PCC and ED /inpatient department while green tags were admitted to ER department of both PCC and ED.

The studied parameters were

I. Clinical Assessment: Medical history with particular emphasis on demographic data such as age, gender and residence in addition to the delay time of intoxication .Physical examination on admission which was subdivided into:

1. General examination for the vital data: temperature, respiratory rate, pulse, blood pressure. Regarding reference values, hypothermia was diagnosed at a temperature below $36.5^{\circ} \mathrm{C}$, fever was diagnosed at a temperature above $37.2^{\circ}$ $\mathrm{C}$ and normal temperature was between $36.5^{\circ} \mathrm{C}-37.2^{\circ} \mathrm{C}$ (Pantell et al., 2004). Tachypnea was diagnosed at a respiratory rate of more than 18 breath /minute; bradypnea was diagnosed at a respiratory rate of less than 12 breath/minute and normal respiratory rate considered between 12-18 breath/minute. A normal breathing rate for an adult at rest is 8 to 16 breaths/minute and for a child, a normal rate is up to 44 breaths/minute (Schriger, 2007). Bradycardia was diagnosed at a heart rate of less than 60 beats /minute, tachycardia was diagnosed at a heart rate of more than 90 beats /minute and normal heart rate 
was between $60-90$ beats/minute (Van Voorhees, 2006). Hypotension was considered if the patient's systolic blood pressure reading was lower than $90 \mathrm{mmHg}$, hypertension was considered if the patient's blood pressure was more than $140 / 90 \mathrm{mmHg}$ and normal blood pressure considered if systolic blood pressure not more than $140 \mathrm{mmHg}$ and diastolic blood pressure not less than $60 \mathrm{mmHg}$ (Van Voorhees, 2006).

2. Systemic examination: Skin examination: inspection of its color, texture, rash, or any other abnormality. Respiratory system examination: air entry and abnormal sounds on auscultation were examined. Cardiovascular examination: heart rate or heart sounds were examined. Neuropsychiatric examination: as regards the level of consciousness of patients under study was graded according to Reed's classification (Mofenson and Caraccio, 1993).Other CNS manifestations like irritability, drowsiness, hallucination, agitation, and convulsions were looked for. Gastrointestinal GIT examination; for vomiting, diarrhea, and abdominal tenderness, hematemesis, melena, constipation, or ileus. Genitourinary system examination; for polyuria, incontinence, hematuria, oligouria or urinary retention.

II. Laboratory data: biological samples were sent for central Lab. Of ministry of health in the form of stools, gastric aspirate and fish samples taken from the kitchen (cooked and raw fish) were examined:

a. Microbiologically: for detection of possible bacteriological causes of food poisoning.

b. Chemical examination: to diagnose any chemical cause of poisoning such as organ phosphorus insecticides, carbamate, heavy metals, histamine and nitrogen.

III. Therapeutic Interventions: Lines of treatment applied were classified according to PCC scombroid fish poisoning treatment protocol into emergency room and inpatient wards treatment which included; antiemetic , antispasmodic , fluid and electrolytes therapy. In addition to anti histaminic (H1 and $\mathrm{H} 2$ receptors blockers) therapy.

IV. Outcome Parameters

$$
\text { A. Cure Rate }
$$
B. Morbidity rate
C. Mortality rate
D. Discharge rate
E. Length of hospital stay in hours

V. Statistical Analysis: Statistical analysis was done using SPSS windows-version 17.

\section{Results}

\section{(I) Clinical Assessment}

Table 1 shows that most of intoxicated patients were between 20-40 years old, males were more than females and most of them come from rural residence. Table 2 shows non-significant difference regarding delay time between the three studied groups.

Table 3 shows that the highly significant GIT manifestations were diarrhea, abdominal colic, tingling and burning peppery taste sensation in studied groups. The highly significant cardiopulmonary manifestations were hypotension, tachycardia, bronchospasm, positive Trendelenberg's position. Neurological manifestations were in the form of highly significant headache in studied groups and significant syncope only in group III. The skin manifestations among the studied groups show highly significant facial flushing, sweating and itching.

\section{(II) Laboratory Investigations}

A) Microbiological examination :

Table 4 shows that microbiological examination of biological samples (stool and gastric aspirate) of studied patient's revealed positive results for Bacillus cereus and Staphylococcus aureus in all samples.

Table 5 shows that microbiological examination of fish samples (fried and raw mackerel fish) revealed positive results for Bacillus cereus and Staphylococcus aureus in $100 \%$ of samples.

B) Chemical Examination:

Table 6 shows highly significant increase in histamine levels in fried and raw mackerel fish samples with non-significant difference in nitrogen level when compared with their permissible levels according to food and drug administration FDA, 2013.

Table 7 shows negative lead and other heavy metals, organophoshorus compounds and carbamate in all of fish samples (fried and raw mackerel fish)

\section{(III) Therapeutic Intervention results}

Table 8 shows that there was highly significant difference statistically between the studied groups of patients with acute scombroid fish poisoning as regards the percentage of different lines of treatment received at ER and inpatient wards of both PCC and ED ASU hospitals.

\section{(IV) Outcome}

Table 9 shows that all cases show complete cure and fully discharged with no morbidities 
or mortalities

Table 10 shows non-significant statistical

difference in the mean length of stay in the inpatient department in both PCC and ED of ASU hospital among the studied groups.

Table 1: Demographic criteria (age, gender \& residence) distribution among the studied patients with acute scombroid fish poisoning admitted to PCC and ED ASU Hospitals first of January 2013

\begin{tabular}{|c|c|c|}
\hline Demographic criteria & Number & Percent $(\%)$ \\
\hline \multicolumn{3}{|c|}{ Age in years } \\
\hline$\leq 20$ years & 18 & $10.2 \%$ \\
\hline $21-40$ years & 131 & $74.9 \%$ \\
\hline 41-60 years & 26 & $14.9 \%$ \\
\hline \multicolumn{3}{|c|}{ Gender } \\
\hline Male & 105 & $60 \%$ \\
\hline Female & 70 & $40 \%$ \\
\hline \multicolumn{3}{|c|}{ Residence } \\
\hline Urban & 75 & $43 \%$ \\
\hline Rural & 100 & $57 \%$ \\
\hline Total & 175 & $100 \%$ \\
\hline
\end{tabular}

Table (2): ANOVA one-way statistical analysis of delay time among studied groups with acute scombroid fish poisoning admitted to PCC and ED ASU hospitals first of January 2013

\begin{tabular}{|c|c|c|c|c|c|}
\hline \multirow{3}{*}{$\begin{array}{c}\text { Delay } \\
\text { Time }\end{array}$} & $\begin{array}{c}\text { Group I } \\
(\mathbf{N}=\mathbf{6 5})\end{array}$ & $\begin{array}{c}\text { Group II } \\
(\mathbf{N}=\mathbf{1 0 0})\end{array}$ & $\begin{array}{c}\text { Group III } \\
(\mathbf{N}=\mathbf{1 0})\end{array}$ & \multirow{2}{*}{ Fc } & \multirow{2}{*}{ CL } \\
\cline { 2 - 6 } & Mean \pm SD & Mean \pm SD & Mean \pm SD & 2.0 & - \\
\cline { 2 - 6 } & $3.6 \pm 1.0$ & $2.0 \pm 0.8$ & $3.0 \pm 1.3$ & - \\
\hline
\end{tabular}

$S D=$ Standard Deviation. $F c=$ variance ratio calculated by ANOVA one-way statistical analysis. CL = confidence limit. Ft $=$ tabulated variance ratio at $P$ 0.05=3.23.

Table 3: Chi square statistical analysis of clinical presentation among the studied groups with acute scombroid fish poisoning admitted to PCC and ED ASU hospitals on the first of January 2013

\begin{tabular}{|c|c|c|c|c|c|c|c|c|}
\hline \multirow{2}{*}{$\begin{array}{l}\text { Clinical } \\
\text { Presentation }\end{array}$} & \multicolumn{2}{|c|}{$\begin{array}{l}\text { Group I } \\
(\mathrm{N}=65)\end{array}$} & \multicolumn{2}{|c|}{$\begin{array}{l}\text { Group II } \\
(\mathbf{N}=100)\end{array}$} & \multicolumn{2}{|c|}{$\begin{array}{l}\text { Group III } \\
(\mathbf{N}=10)\end{array}$} & \multirow[t]{2}{*}{$\mathbf{X} 2$} & \multirow[t]{2}{*}{$\mathbf{P}$} \\
\hline & N. & $\%$ & $\mathrm{~N}$. & $\%$ & N. & $\%$ & & \\
\hline \multicolumn{9}{|c|}{ GIT Manifestations } \\
\hline Nausea & 20 & 31 & 15 & 15 & 2 & 20 & 63.7 & $>0.05$ \\
\hline Vomiting & 13 & 20 & 30 & 30 & 4 & 40 & 33.7 & $>0.05$ \\
\hline Diarrhea & 5 & 8 & 65 & 65 & 9 & 90 & 60.4 & $0.000 * *$ \\
\hline Abdominal Colic & 23 & 36 & 40 & 40 & 6 & 60 & 70.2 & $0.000 * *$ \\
\hline Tingling and Burning peppery taste & 35 & 54 & 80 & 80 & 9 & 90 & 78.2 & $0.000 * *$ \\
\hline \multicolumn{9}{|c|}{ Cardiopulmonary manifestations } \\
\hline Hypotension & 55 & 80 & 68 & 68 & 9 & 90 & 67.9 & $0.000 * *$ \\
\hline Hypertension & - & - & - & - & 1 & 10 & - & $>0.05$ \\
\hline Normal Blood Pressure & 10 & 15 & 32 & 32 & - & - & 5.4 & $>0.05$ \\
\hline Tachycardia & 65 & 100 & 68 & 68 & 9 & 90 & 78.9 & $0.000 * *$ \\
\hline Bradycardia & - & - & - & - & 1 & 10 & - & $>0.05$ \\
\hline Normal Pulse rate & - & - & 32 & 32 & - & - & - & $>0.05$ \\
\hline Bronchospasm & 19 & 29 & 78 & 78 & 8 & 80 & 50.4 & $0.000 * *$ \\
\hline Trendeleberg positioning & 29 & 30 & 80 & 80 & 9 & 90 & 61.6 & $0.000 * *$ \\
\hline \multicolumn{9}{|c|}{ Neurological manifestations } \\
\hline Headache & 55 & 85 & 75 & 75 & 8 & 80 & 63.7 & $0.000 * *$ \\
\hline Syncope & - & - & - & - & 8 & 80 & 39.8 & $0.005^{*}$ \\
\hline \multicolumn{9}{|c|}{ skin } \\
\hline Facial flushing & 29 & 45 & 43 & 43 & 9 & 90 & 64.8 & $0.000 * *$ \\
\hline Sweating & 35 & 54 & 70 & 70 & 9 & 90 & 68.6 & $0.000 * *$ \\
\hline Itching & 60 & 92 & 85 & 85 & 9 & 90 & 78.2 & $0.000 * *$ \\
\hline
\end{tabular}

$* * P<0.01$ Highly Significant $X 2=$ Chi square value $N=$ number of cases 
Table 4: Percentage of microbiological examination of biological samples (stools and gastric aspirate) of all studied groups of patients (175 cases)

\begin{tabular}{|l|l|l|l|l|}
\hline \multirow{2}{*}{ Types of bacteria } & \multicolumn{3}{|l|}{ Biological Samples of the 175 cases } \\
\cline { 2 - 5 } & Stool & \multicolumn{2}{l|}{ Gastric Aspirate } \\
\cline { 2 - 5 } & Positive & Negative & Positive & Negative \\
\hline Bacillus cereus & $100 \%$ & - & $100 \%$ & - \\
\hline Enteroinvasive E-coli & - & $100 \%$ & - & $100 \%$ \\
\hline Enterotoxigenic E-coli & - & $100 \%$ & - & $100 \%$ \\
\hline Group A Streptococci & - & $100 \%$ & - & $100 \%$ \\
\hline Staphylococcus aureus & $100 \%$ & & $100 \%$ & \\
\hline
\end{tabular}

Table 5: Percentage of Microbiological examination of fish samples (fried and raw mackerel fish)

\begin{tabular}{|l|l|l|l|l|}
\hline \multirow{3}{*}{ Types of bacteria } & \multicolumn{4}{|c|}{ Fish Samples } \\
\cline { 2 - 5 } & Fried mackerel fish & Raw macker fish \\
\cline { 2 - 5 } & Positive & Negative & Positive & Negative \\
\hline Bacillus cereus & $100 \%$ & - & $100 \%$ & - \\
\hline Enteroinvasive E-coli & - & $100 \%$ & - & $100 \%$ \\
\hline Enterotoxigenic E-coli & - & $100 \%$ & - & $100 \%$ \\
\hline Group A Streptococci & - & $100 \%$ & - & $100 \%$ \\
\hline Staphylococcus aureus & $100 \%$ & & $100 \%$ & \\
\hline
\end{tabular}

Table 6: ANOVA one-way statistical analysis of chemical examination of fried and raw mackerel fish samples

\begin{tabular}{|c|c|c|c|c|c|}
\hline \multirow{2}{*}{ Chemical examination } & Fried Mackerel Fish & Raw Mackerel Fish & \multirow{2}{*}{ The permissible level } & \multirow{2}{*}{ Fc } & \multirow{2}{*}{ CL } \\
\hline & Mean \pm SD & Mean \pm SD & & & \\
\hline $\begin{array}{l}\text { Histamine level } \\
\text { in } \mathrm{mg} / 100 \text { grams }\end{array}$ & $75 \pm 5.0$ & $95 \pm 5.0$ & 10 & 9.7 & 34.7 \\
\hline $\begin{array}{l}\text { Nitrogen level } \\
\text { in } \mathrm{mg} / 100 \text { grams }\end{array}$ & $7.5 \pm 1.9$ & $7.2 \pm 1.5$ & 7.7 & 1.5 & 0.04 \\
\hline
\end{tabular}

$S D=$ Standard Deviation. $F c=$ variance ratio calculated by ANOVA one-way statistical analysis. CL $=$ confidence limit. Ft $=$ tabulated variance ratio at $P 0.05=3.78$.

Table 7: Percentage of chemical examination for lead and other heavy metals, organophoshorus compounds and carbamate in fish samples (fried and raw mackerel fish)

\begin{tabular}{|l|l|l|l|l|}
\hline \multirow{2}{*}{\multicolumn{2}{c|}{ Chemical examination }} & \multicolumn{4}{c|}{ Fish Samples } \\
\cline { 2 - 5 } & Fried mackerel fish & Raw mackerel fish \\
\cline { 2 - 5 } & Positive & Negative & Positive & Negative \\
\hline Lead and other heavy metals by Reinch's test & - & $100 \%$ & - & $100 \%$ \\
\hline Organophosphorus compounds & - & $100 \%$ & - & $100 \%$ \\
\hline Carbamate & - & $100 \%$ & - & $100 \%$ \\
\hline
\end{tabular}

Table 8: Chi square statistical analysis of different lines of treatment received by studied groups of patients with acute scombroid fish poisoning admitted as mass casualty PCC and ED ASU hospitals on the first of January 2013

\begin{tabular}{|c|c|c|c|c|c|c|c|c|}
\hline \multirow{2}{*}{ Different Lines of treatment } & \multicolumn{2}{|c|}{$\begin{array}{c}\text { Group I } \\
(\mathrm{N}=65)\end{array}$} & \multicolumn{2}{|c|}{$\begin{array}{c}\text { Group II } \\
(\mathbf{N}=100)\end{array}$} & \multicolumn{2}{|c|}{$\begin{array}{c}\text { Group III } \\
(\mathbf{N}=10)\end{array}$} & \multirow[t]{2}{*}{$\mathbf{X} 2$} & \multirow[t]{2}{*}{$\mathbf{P}$} \\
\hline & $\mathbf{N}$ & $\%$ & $\mathbf{N}$ & $\%$ & $\mathbf{N}$ & $\%$ & & \\
\hline Antiemetic & 20 & 30.8 & 30 & 30 & 6 & 60 & 3.9 & $0.000 * *$ \\
\hline Antispasmodics & 55 & 84.6 & 40 & 40 & 6 & 60 & 3.7 & $0.000 * *$ \\
\hline Intravenous fluids and electrolyte therapy & 15 & 23.1 & 65 & 65 & 9 & 90 & 4.2 & $0.000 * *$ \\
\hline H1 andH2 receptor blocker and systemic antihistamines & 23 & 35.4 & 85 & 85 & 9 & 90 & 5.6 & $0.000 * *$ \\
\hline
\end{tabular}

$* * P<0.01$ Highly Significant $X 2=$ Chi square value $N=$ number of cases

Table 9: Percentage of outcome among studied groups of patients with acute scombroid fish poisoning admitted to PCC and ED ASU Hospitals on the first of January 2013

\begin{tabular}{|l|c|c|c|c|c|c|}
\hline \multirow{3}{*}{ Outcome } & \multicolumn{2}{|c|}{$\begin{array}{c}\text { Group I } \\
(\mathbf{N = 6 5})\end{array}$} & \multicolumn{2}{c|}{$\begin{array}{c}\text { Group II } \\
(\mathbf{N = 1 0 0}\end{array}$} & \multicolumn{2}{c|}{$\begin{array}{c}\text { Group III } \\
(\mathbf{N = 1 0})\end{array}$} \\
\cline { 2 - 7 } & $\mathbf{N}$ & $\mathbf{\%}$ & $\mathbf{N}$ & $\mathbf{\%}$ & $\mathbf{N}$ & \% \\
\hline Complete cure & 65 & 100 & 100 & 100 & 10 & 100 \\
\hline Morbidities & - & - & - & - & - & - \\
\hline
\end{tabular}




\begin{tabular}{|l|l|l|l|l|l|l|}
\hline Mortalities & - & - & - & - & - & - \\
\hline Full discharge & 65 & 100 & 100 & 100 & 10 & 100 \\
\hline
\end{tabular}

Table 10: ANOVA one-way statistical analysis of length of hospital stay LOHS in hours among the studied groups of patients with acute scombroid fish poisoning admitted to PCC and ED ASU hospitals on the first of January 2013.

\begin{tabular}{|c|c|c|c|c|c|}
\hline \multirow{3}{*}{ LOHS/hour } & $\begin{array}{c}\text { Group I } \\
(\mathbf{N}=\mathbf{6 5})\end{array}$ & $\begin{array}{c}\text { Group II } \\
(\mathbf{N}=\mathbf{1 0 0})\end{array}$ & $\begin{array}{c}\text { Group III } \\
(\mathbf{N}=\mathbf{1 0})\end{array}$ & \multirow{2}{*}{ Fc } \\
\cline { 2 - 6 } & Mean \pm SD & Mean \pm SD & Mean \pm SD & & \\
\cline { 2 - 7 } & $8 \pm 0.45$ & $10 \pm 0.25$ & $12 \pm 0.33$ & 2.0 & 5.84 \\
\hline
\end{tabular}

$S D=$ Standard Deviation. $F c=$ variance ratio calculated by ANOVA one-way statistical analysis. $C L=$ confidence limit. $F t=$ tabulated variance ratio at $P 0.05=3.0$

\section{Discussion}

On the first of January 2013 one hundred and seventy five workers in one of El Obour factories were admitted to PCC and ED ASU hospitals as mass casualty after consuming a mackerel fish lunch in their work. The demographic data revealed that $75 \%$ of patients were adults from twenty to forty years old, $60 \%$ of them were males and $57 \%$ came from rural areas.

These results were in agreement with Fein et al., 2014 who estimated that most cases of scombroid fish poisoning occurred mainly in male gender and more likely among people from 18 to 39 years of age.

The affection of adult age group and male gender in this study could be explained by the fact that high percentage of workers in industrial areas like El Obour city are mainly from adult males that are coming mainly from rural residence to earn their living by working in urban industries for better salary.

The present work proved that there was nonsignificant differences regarding delay time between the studied three groups of patients with acute scombroid fish poisoning admitted to PCC and ED of ASU hospital.

This could be explained by the fact that although cases were admitted to PCC and ED ASU hospital with unequal delay time interval of admission among the three studied groups of patients, this inequality of delay time didn't affect the severity of clinical manifestations which could reflect the efficacy of the applied emergency plan for mass casualty incident.

The clinical assessment results revealed highly significant statistical difference between the studied groups regarding gastrointestinal manifestations (in the form of diarrhea, abdominal colic, and tingling and burning peppery taste sensation), and cardiopulmonary manifestations (in the form of hypotension, tachycardia, bronchospasm, positive Trendelenberg's position). Neurological manifestations in the form of headache were highly significant in the studied groups and significant syncope only in group III. The skin manifestations among the studied groups showed highly statistical significant facial flushing, sweating and itching.

The clinical presentation of the cases were typical of an outbreak of scombrotoxin fish poisoning' appearing shortly after consuming suspected fish meal and resolving within several hours. Scombroid fish poisoning, or histamine fish poisoning, is a syndrome resembling an allergic reaction that occurs after eating fish contaminated with high levels of histamine, manifested by symptoms that include tingling sensations around the mouth, facial flushing, sweating, minimal or absent nausea and vomiting, marked headache, palpitations, and skin rash in the form of erythema in the upper part of the body ( Goldfrank , 2013).

Also Lehane and Olley (2013) reported many outbreaks of scombroid fish poisoning all over the world and revealed that patients exposed to histamine fish poisoning experienced flushing of the face and sometimes the neck, arms, and upper part of the trunk; severe headache; tachycardia;, abdominal pain, and/or short term diarrhea; itching on the face or around the mouth and rash.

In the current work biological samples from gastric aspirate of patients as well as from raw and cooked fish were sent to the central laboratory of ministry of health for microbiological and chemical examination. Microbiological examination revealed the presence of bacillus cereus and staphylococcus aureus.

Elevated levels of bacteria in the cooked and raw fish are not uncommon in kitchens, as mackerel fish are excellent media for bacterial growth especially if they are unfrozen or insufficiently cooked. Also the presence of high bacteria levels in the apparently intact fish could be explained by poor process of hygiene at or prior to packing, as bacterial growth should not have taken place in frozen fish. The combination of bacteria in the mackerel fish plus an extended period of uncontrolled temperature in the kitchen could create a 'perfect storm' to create the very high histamine levels that cause symptoms, according to HACCP system (2013).

Diseases caused by $B$. cereus are commonly found in places where there is improper food handling. Between the year 1973 and 1985, B. cereus caused $17.8 \%$ of the total bacterial food poisonings in Finland, $11.5 \%$ in the Netherlands, $0.8 \%$ in Scotland, $0.7 \%$ in England and Wales, $2.2 \%$ in Canada, $0.7 \%$ in Japan, and $15.0 \%$ in Hungary. In Norway, B. cereus was the most common microbe isolated from food borne illnesses in 1990. In 2008, 103 confirmed outbreak cases have been reported in the US (Logan, \& Rodrigez-Diaz, 2012). 
The primary mode of transmission is via the ingestion of $B$. cereus contaminated food where $B$. cereus could cause two types of food-borne illnesses. One type is characterized by nausea, vomiting and abdominal cramps and has an incubation period of 1 to 6 hours. This is the "short-incubation" or emetic form of the disease. The short-incubation form is most often associated with rice dishes that have been cooked and then held at warm temperatures for several hours (Pukall et al., 2013) .The second type is manifested primarily by abdominal cramps and diarrhea following an incubation period of 8 to 16 hours. Diarrhea may be of a small volume or profuse and watery. This type is referred to as the "long-incubation" or diarrheal form of the disease, and it resembles food poisoning caused by Clostridium perfringens. In both types, the illness usually lasts less than 24 hours after onset (Rosovitz, Voskuil \& Chambliss, 2013).

The short-incubation or emetic form of the disease is diagnosed by the isolation of B. cereus from the incriminated food. The long-incubation or diarrheal form is diagnosed by isolation of the organism from stool and food. Isolation from stools alone is not sufficient because $14 \%$ of healthy adults have been reported to have transient gastrointestinal colonization with $B$. cereus. Because $B$. cereus gastroenteritis is generally a benign, self-limited illness, antimicrobial agents are of no value in management. Since the bacteria grow best at temperatures ranging from 40 to $140^{\circ} \mathrm{F}$, infection may be prevented if cold food is refrigerated and if hot food is held at greater than $140^{\circ} \mathrm{F}$ before serving (Kotiranta, Lounatmaa \& Haapasalo, 2013).

Staphylococcus aureus is a type of bacteria commonly found on the skin and hair as well as in the noses and throats of people and animals. These bacteria are present in up to 25 percent of healthy people and are even more common among those with skin, eye, nose, or throat infections (Iwase et al., 2013).Staphylococci can cause food poisoning when a food handler contaminates food and then the food is not properly refrigerated. Other sources of food contamination include the equipment and surfaces on which food is prepared. These bacteria multiply quickly at room temperature to produce a toxin that causes illness .Staphylococci are killed by cooking or pasteurization (Menichetti, 2013).The most common food sources of staph aureus are those that are made with hand contact and require no additional cooking such as salads, tuna, sandwiches and bakery products. Other sources include milk and dairy products as well as meat, eggs and sea food. The incubation period is one to 6 hours .Symptoms are usually in the form of nausea, vomiting, diarrhea, loss of appetite, severe abdominal cramps and mild fever. The condition is usually self-limiting even without use of antimicrobials (Francois and Schrenzel , 2013).

The presence of bacteria in biological samples and fish samples in this study could explain the first preliminary diagnosis of El Salam general hospital of bacterial food poisoning since the gastro intestinal manifestations were evident.
In the present study the chemical examination for both cooked fried and raw unfrozen mackerel fish reveled very high level of histamine more than permissible level which is $10 \mathrm{mg} / 100$ grams according to Food and Drug Administration (FDA).

Scombroid syndrome can result from inappropriate handling of fish during storage or processing. One of the toxic agents implicated in scombroid poisoning is histidine, which is broken down into histamine. Other chemicals have been found in decaying fish flesh, but their association with scombroid fish poisoning has not been clearly established (Hungerford, 2010).

Histadine exists naturally in many types of fish, and at temperatures above $16^{\circ} \mathrm{C}\left(60^{\circ} \mathrm{F}\right)$ on air contact it is converted to the biogenic amine histamine via the enzyme histidine decarboxylase produced by enteric bacteria including Morganella morganii (this is one reason why fish should be stored at low temperatures). Histamine is not destroyed by normal cooking temperatures, so even properly cooked fish can be affected. Histamine is a mediator of allergic reactions, so the symptoms produced are those one would expect to see in severe allergic responses ( Ansdell, 2013).Fish from the family scombridae (e.g., tuna and mackerel) contain high levels of free histidine in muscle tissue and are the most common sources of scombroid fish poisoning; however, other fish (e.g., mahi mahi, amberjack, bluefish, abalone, and sardines) also have been implicated ( Wilson, 2013).

The chemical examination results of this study was in agreement with the laboratory results conducted from samples of fish following the largest reported outbreak of scombroid fish poisoning in United states ,2013 where samples showed markedly elevated histamine levels (from 2000 to $3800 \mathrm{ppm}$ or $70-95 \mathrm{mg} / 100$ grams). The results were in accordance with FDA laboratory testing of certain cafeteria in Boston after an outbreak of scombroid fish poisoning following consumption of tuna steaks in April 2013. Laboratory testing of tuna steaks from the cafeteria detect elevated histamine levels (>50 mg/100 g). The fish had been imported from Indonesia through Boston and shipped frozen to the Louisiana distributor. During the trace back investigation by FDA, histamine levels $>50 \mathrm{mg} / 100 \mathrm{~g}$ were detected in tuna steaks from a shipment that a local distributor had used to supply the refinery cafeteria. Fish in the implicated shipment had not been distributed to any other facilities, and all remaining product was destroyed. FDA trace back investigation of the tuna shipment did not detect any breaches in temperature control, indicating that any temperature breaches likely occurred between the time the fish was caught and the time it arrived in Boston. Additional preventive measures included a product recall by the distributor in Boston and an FDA import alert regarding the Indonesian firm that supplied the tuna steaks (Jantschitsch et al., 2013).

The most effective prevention for scombroid fish poisoning is proper refrigeration of fish at $\leq 40^{\circ} \mathrm{F}$ $\left(\leq 4.4^{\circ} \mathrm{C}\right)$ at all times between catching and 
consumption. Sensory examination (by smell and tastes) is not sufficient to detect the absence or presence of histamine; chemical testing is required (Murray et al., 2013). Unlike many bacterial pathogens, histamine is not destroyed when fish are frozen or cooked, making adherence to temperature requirements along all stages of the food supply chain essential.

According to Food and Drug Administration (FDA), 2013 which reported that health-care personnel considered scombroid fish poisoning in their initial differential diagnoses on the basis of symptoms and exposure to seafood. The restaurants in which the implicated seafood was served were notified and responded by removing the implicated seafood from the menu to prevent additional exposure and potential illness. FDA testing detected elevated histamine levels in the Louisiana outbreak and facilitated additional food-safety preventive measures in their trace back responses to both outbreaks (Morrow et al., 2013)

On the other hand Feldman et al., (2013) reported that although elevated histamine levels have been identified in the samples of cooked and raw fish routine diagnosis is based mainly on clinical signs and a history of fish consumption.

In the present study after symptomatic treatment of all cases with antihistaminic, spasmolytics , I.V fluids and electrolytes followed by clinical observation for eight hours, all patients showed significant cure and there were no mortalities or morbidities associated with complete discharge of all patients.

These results agreed with studies in the United States and Europe where scombroid fish poisoning accounts for up to 40 percent of seafood-borne illness outbreak. Between 1998 and 2002, there were 167 scombroid outbreaks reported to the United States Centers for Disease Control and Prevention that affected 703 persons, 38 of whom were hospitalized and none of them died (Gould et al. 2013). The main line of treatment of scombroid food poisoning is in the form of supportive care such as fluids and oxygen. H1 and $\mathrm{H} 2$ receptor (histamine receptors) blocking medications can also be given with some success. Oral anti-histamines are very effective, showing improvement within 10-15 minutes (Hungerford, 2010).

The non-significant difference between the delay time in all patients groups mild, moderate and severe and the outcome of such patients revealed the effectiveness of the emergency mass casualty plan and efficacy of therapeutic intervention applied in PCC and ED of ASU hospitals.

The length of hospital stay in the inpatient department of PCC and ED of internal medicine, ASU hospitals revealed that there was non-significant difference in the mean hours of hospital stay among group I ( $8 \pm 0.45$ hours), group II ( $10 \pm 0.25$ hours $)$ and group III (was $12 \pm 0.33$ hours).

This is in accordance with data declared by Prester (2013) who reported that scombroid food poisoning symptoms usually last for 8 to 12 hours, after which most persons recover rapidly after effective therapeutic measures. Also Stratta and Badino (2012) revealed in their study that the symptoms of acute scombroid fish poisoning can be shown within just minutes, and usually last for about 10 to 14 hours, and rarely exceed one to two days .

On the other hand Vickers and Safai (2013) reported that histamine fish poisoning occurs very quickly after eating unfrozen fish, usually within 30 minutes to a few hours. Symptoms usually last for 4 to 6 hours and rarely exceed one day.

Also the length of hospital stay results support the previous results that proved non-significant correlation between the delay time and clinical manifestations and proved that although group II and III patients presented with more delay time, more clinical manifestations their outcome was the same with complete cure rate no mortalities or morbidities and complete discharge of all patients that reflected the effectiveness of emergency management plan for mass casualty incident application .

\section{Conclusion}

Diagnosis of Scombroid food poisoning is merely based on history and clinical findings and laboratory results should be kept as an aiding tool to confirm the clinical diagnosis.

Emergency management plan for mass casualty in scombroid fish poisoning with therapeutic intervention for each group and supervision should be started immediately upon suspicion of toxicity for proper outcome.

This study concluded the importance of proper temperature regulation especially for fish belonging to scombroidea fish family to reduce the incidence of scombroid fish poisoning.

\section{Recommendations}

The current study recommend that the number of available beds in PCC should be increases to enlarge its capabilities of facing mass casualty incidents.

Training a specialized toxicologist's team on mass disaster management program should be available as continuous medical education programs for junior staff.

Proper temperature control and preservation of fish food especially those belonging to scombroidea family is mandatory to avoid bacterial contamination and high histamine level.

Tuna and mackerel fish should always purchase from reputable suppliers who store the fish frozen on ice and food handlers should thaw the frozen fish under refrigeration. Preparation of food should be according to national and International guidelines.

\section{References}

Ansdell V (2013): Food-borne illness. In: Keystone JS, Freedman DO, Kozarsky PE, Connor BA, Nothdurft HD, editors. Travel Medicine. 3rd ed. Philadelphia: Saunders Elsevier; p. 42532.

Centers for Disease Control and Prevention (2011): Surveillance for foodborne disease outbreaks- 
United States, morbidity and mortality Weekly Report, 59(31):973-979.

Fein et al., (2014): Journal of Food Protection $®$, Number 12, pp. 1294-1411, pp. 1405-1411(7)

Feldman KA, Werner SB, Cronan S, et al., (2013): A large outbreak of scombroid fish poisoning associated with eating escolar fish (Lepidocybium flavobrunneum). Epidemiol Infect. Feb 2005; 133(1):29-33.

Food and Drug Administration (2013): Fish and fisheries products hazards and controls guidance. 3rd ed. Scombrotoxin (histamine) formation: a chemical hazard.

Francois P and Schrenzel J (2013): Rapid diagnosis and typing of Staphylococcus aureus". Staphylococcus: Molecular Genetics. Caister Academic Press. ISBN 978(1): 45569.

Goldfrank LR (2013): Goldfrank's Toxicological Emergencies. 9th ed. New York, NY: McGraw-Hill.

Gould LH, Walsh KA, Vieira AR, et al., (2013): Surveillance for foodborne disease outbreaks United States, 1998-2012. MMWR Surveillance; 62:1.

Hungerford JM (2010): Scombroid poisoning: a review.

Toxicon. 15; 56(2):231-43.

HACCP system ( 2013) : Hazards Analysis Critical Care Point Standards .

Iwase $\mathrm{T}$, Uehara $\mathrm{Y}$, Shinji $\mathrm{H}$ et al., (2013): Staphylococcus epidermidis inhibits Staphylococcus aureus biofilm formation and nasal colonization. Nature 465 (7296): 346-9.

Jantschitsch C, Kinaciyan T, Manafi $M$ et al., (2013): Severe scombroid fish poisoning: an underrecognized dermatologic emergency. J Am Acad Dermatol ; 65:246-7.

Kotiranta A, Lounatmaa K, \& Haapasalo M (2013): Epidemiology and pathogenesis of Bacillus cereus infections. Microbes and Infection, 2(2), 189-198.

Lehane L and Olley J (2013): Histamine fish poisoning revisited. Int J Food Microbiol; 58(1), 211216.

Logan NA, \& Rodrigez-Diaz M (2012): Bacillus spp. and Related Genera. In S. H. Gillespie, \& P. M. Hawkey (Eds.), Principles and Practice of Clinical Bacteriology (2nd ed., pp. 139-158). West Sussex, England, UK: John Wiley and Sons Ltd.
Menichetti F (2013): Current and emerging serious Gram-positive infections. Clin Microbiol Infect 11 (3): 22-8.

Mofenson HC, and Caraccio TR, (1993):

Intial evaluation and management of the poisoned patient. In: Handbook of Medical Toxicology.Viccello P, (ed), Little Brown and Company, London.pp 47-105.

Morrow JD, Margolies GR, Rowland J et al., (2013): Evidence that histamine is the causative toxin of scombroid-fish poisoning. N EnglJ Med; 324:716-20.

Murray PR, Baron EJ, Jorgensen JH et al, . (2013): Manual of Clinical Microbiology (9th Ed.) American Society of Microbiology Press.

Pantell RH, Newman TB, Bernzweig J, et al., (2004):

Management and outcomes of care of fever in early infancy. JAMA; 291(10):1203-1212.

Prester L (2013): Biogenic amines in fish, fish products and shellfish: a review. Food Addit Contam Part A Chem Anal Control Expo Risk Assess. ; 28(11):1547-60.

Pukall R, Schumann P, Granum PE, et al., (2013): Toxin-producing ability among Bacillus spp. outside the Bacillus cereus group. Applied and Environmental Microbiology, 71(3), 11781183.

Rosovitz MJ, Voskuil M I, \& Chambliss GH (2013): Bacillus. In L. Collier, A. Balows, M. Sussman, A. Balows \& B. I. Duerden (Eds.), Topley \& Wilson's Microbiology and Microbial Infection: Systematic Bacteriology (9th ed., pp. 709-729). USA: Arnold.

Schriger DL (2007):

Approach to the patient with abnormal vital signs. In: Cecil Medicine, Goldman L, Ausiello D, (eds), 23rd ed, Saunders Elsevier, Philadelphia, Chapter (7) pp: 233-237.

Stratta P and Badino G (2012): Scombroid poisoning. CMAJ; 184:674.

Van Voorhees BW, (2006): Blood pressure. Medical Encyclopedia,U.S. National Library of Medicine, National Institutes of Health.

Vickers J and Safai B (2013): Images in clinical medicine. Scombroid poisoning. $\mathrm{N}$ Engl J Med; 368:31.

Wilson BJ (2013): A case of histamine fish poisoning in a young atopic woman. J Gen Intern Med. Jul 2012; 27(7):878-81. 


\section{الملخص العربى}

\section{الإصابة الجماعية بالتسمم السمك الإسقمري بين عمال مصنع بمدينة العبور}

\section{هبه يوسف و مني القطب موسى' و سعد نجيب؟}

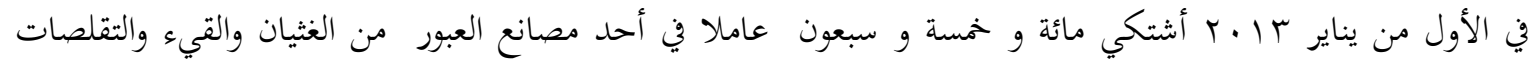

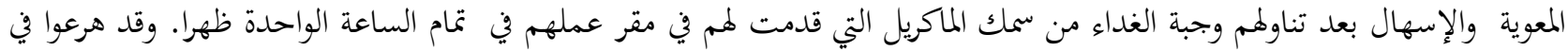

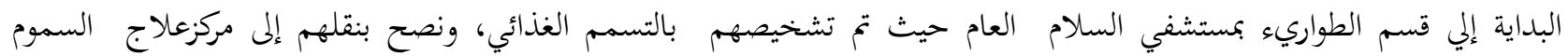

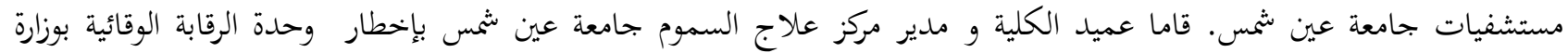

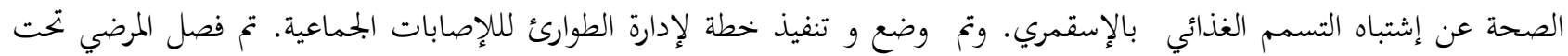

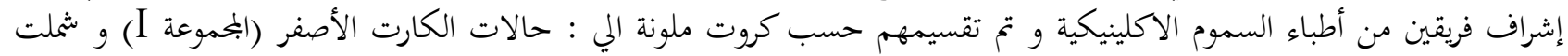

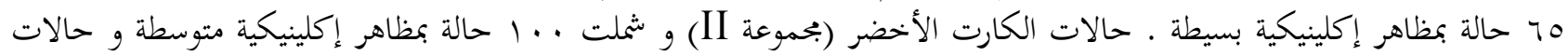

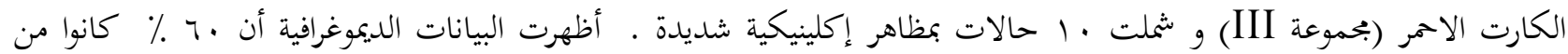
الذكور و •ع \% من الإناث.

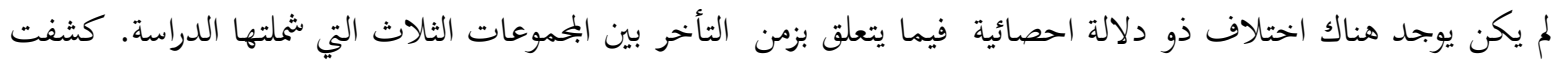

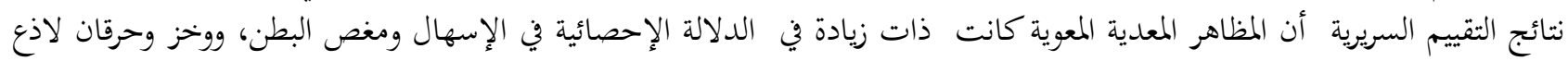

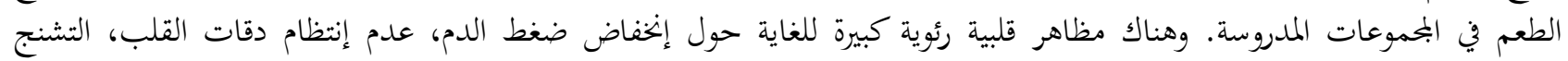

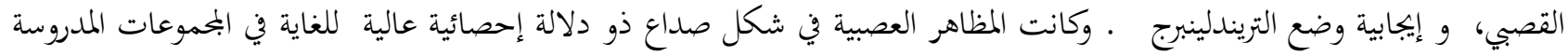

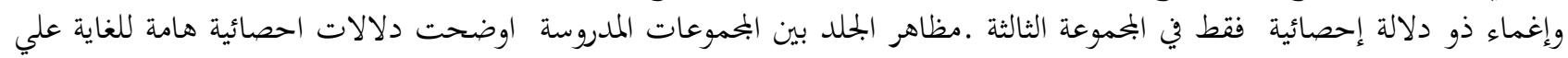

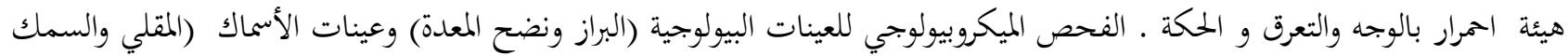

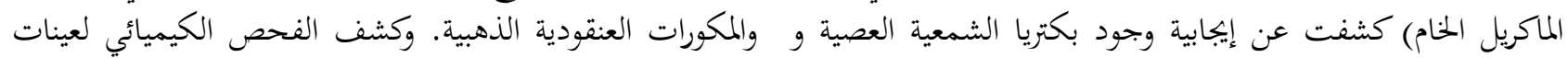

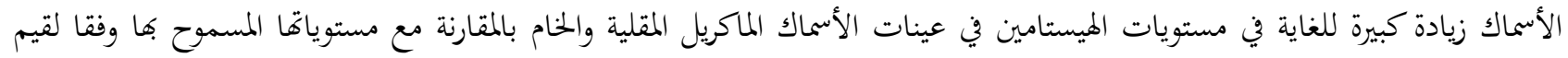

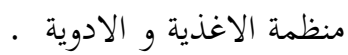

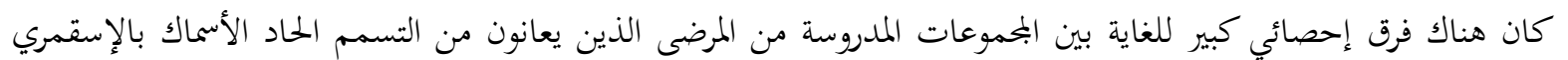

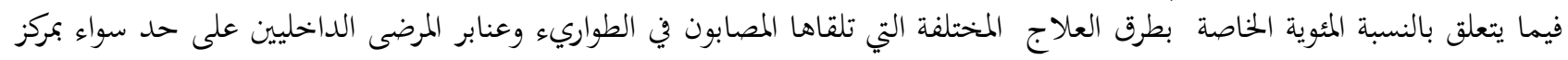

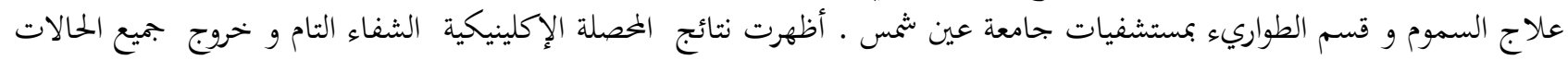

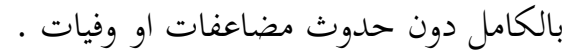
و استنتجت الدراسة ان الإصابات الجماعية لحوادث التسمم باسماك الاسقمري يمكن ان تمر بسلام إذا تم تنفيذ خطة إدارة

و توصي الدراسة بضرورة زيادة عدد الاسرة المتاحة بمركز علاج السموم لزيادة قدرته علي مواجهة الإصابات الجماعية . كما

$$
\text { الطواريء بنجاح }
$$

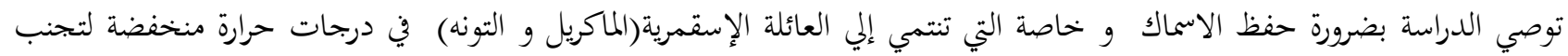

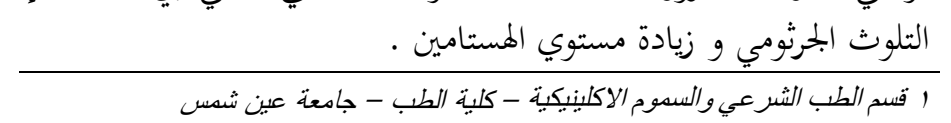

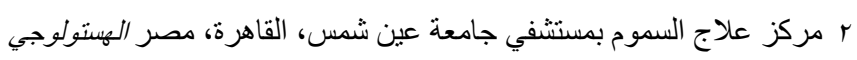

